\title{
The Impact of Internet Finance on the Systemic Risk of China's Listed Commercial Banks
}

\author{
Hanyang Liu ${ }^{1, *}$ \\ ${ }^{1}$ Capital University of Economics and Business, China \\ *Corresponding author.Email:lhy0617@cueb.edu.cn
}

\begin{abstract}
To explore the impact of Internet Finance on the systemic risk of listed commercial banks and maintain the stable development of the macro-financial market, this paper analysis the theoretical mechanism of Internet Finance and systemic risk of commercial banks and selects 16 listed commercial banks in China $\beta$. The results show that the development of Internet finance has a significant role in promoting the systemic risk of commercial banks. Users' stickiness to Internet finance will aggravate the emergence of systemic risk of commercial banks. This enlightens commercial banks to innovate in business philosophy and business management to effectively reduce risks.
\end{abstract}

Keywords: Internet finance, Commercial bank, Systemic risks.

\section{INTRODUCTION}

\subsection{Research Background}

In recent years, with the emergence of cloud computing technology and big data technology, Internet finance can more appropriately push targeted services based on customers' historical consumption experience. It further improves the efficiency of financial services, which is beyond comparison with traditional finance. The development of Internet finance in China is at the forefront of the world, which is due to a variety of factors. First, newer and faster Internet technologies provide sufficient technical support for Internet enterprises to intervene in the financial field. Due to the continuous update of Internet transmission technology and the gradual maturity of big data applications, a large number of Internet enterprises have been driven to layout Internet financial business. The financial business of Internet enterprises such as Alibaba, Tencent, Baidu, Meituan, and Jingdong involves many fields such as payment and settlement, consumer lending, and fund insurance sales. Secondly, the Internet customer base is expanding rapidly with the development of smartphones. China's Internet has fully stepped into the mobile Internet era, further promoting the formation of a new financial pattern with Internet finance as the main activity. According to the Statistical Report on the Development of Internet in China released by the China Internet Network Information Center (CNNIC) on
February 3, 2021, by December 2020, the number of Internet users reached 988.99 million, and the Internet penetration rate reached $70.4 \%$. China has 986 million mobile Internet users, and 99.7 percent of Internet users use mobile phones to surf the Internet. According to the survey, $37.77 \%$ of the people who participate in Internet financial investment have been exposed to Internet financial products, and the trend is expanding [1]. At present, more Chinese citizens are used to transferring money and paying through the Internet, and more people choose to shop online instead of offline physical shopping. The simple, convenient, and fast Internet experience has had a huge impact on people's consumption and payment habits.

At the same time, China's market development progress has not yet formed a complete financial system, making it difficult for most Chinese citizens to participate in financial activities before the development of the Internet. The cost of participation is high, and the main problem is that there are few investment channels. At the same time, before the popularization of the Internet, the overall efficiency of the financial market was low, and financing was difficult. Traditional commercial banks also had their own drawbacks. Traditional commercial banks follow the "80-20 law" in their operation decisions [2]. The commodities that account for $20 \%$ of the market can bring $80 \%$ of the market profits. Shortcomings in this aspect have been significantly improved in Internet finance. Using the Long Tail theory and the advantage of relatively low 
cost, Internet finance has solved the financing difficulties of the majority of small and micro customers, making the financial participants more diversified and the overall financial capital more expanded. Because of the Internet financial payment settlement is the main mode of development, finance, insurance and finance four business, the four aspects of the intermediary business of commercial Banks, assets and liabilities side impact, commercial Banks have to reduce the behavior of loan threshold, the long-term development in such an environment may cause the liquidity risk of commercial Banks, risk of default risk and profit, and so on and so forth, even the bank's overall systemic risk.

Therefore, in this context, attention should be paid to the impact of Internet finance on commercial banks. Although Internet finance is an effective innovation, it has direct and indirect risk contagion and risk spillover. The resulting impact on the main business of traditional commercial banks may lead to a series of risk releases. Commercial Banks under the Internet financial shocks, innovative business development shall be conducted, by combining the advantages of the Internet financial business on expanding our scope of business involves himself. When offer more convenient service to focus on Internet financial impact on the overall systemic risk of the commercial bank, they maintain the stability of China's overall financial system, to avoid grey rhino events.

\subsection{Research Significance}

At present, the research on the impact of Internet finance on commercial banks in the academic circle mostly appears in the analysis of commercial banks' risk-taking and liquidity level by Internet finance, and there is still a large space for the research on the systemic risk of the banking industry. Based on the existing research, this paper combines qualitative and quantitative research. It focuses on the quantitative part of the study on the impact of Internet finance on the systemic risk of banks, which enriches the current theoretical research on Internet finance and the systemic risk of commercial banks. In 2008, due to the outbreak of the subprime mortgage crisis in the United States, a large-scale financial tsunami was formed, and a large number of banks went bankrupt and liquidated. This phenomenon profoundly affected the financial pattern of the United States and even changed the financial pattern of the world. In recent years, with trade, the trade friction between China and the United States, combined with COVID - 19, the world economic environment is more and more complex, the management circumstance of banking institutions with change, constantly by introducing innovative financial products to obtain greater profits. On top of this, the emergence of the Internet financial makes the complexity more vulnerable to deepening China's banking system. Especially in the context of China's recent strengthening of control over Internet finance and Internet enterprises, reassessment of the impact of Internet finance on commercial banks can provide a better reference for the formulation of financial regulatory measures. It is of great practical significance to study the influence of Internet finance on the systemic risk of the banking industry to reduce the spillover effect of Internet finance and maintain the stable development of macro-finance

\subsection{Literature Review}

\subsubsection{The Study of Related Concepts}

\subsubsection{Study on the Definition of Systemic Risk in $\underline{\text { Banking Industry }}$}

The first type is the school represented by Kaufman [3], which defines bank systemic risk as "the probability of a series of losses in a series of financial institutions or markets and then cumulative losses"., identified systemic risk in the banking sector as a chain reaction. This is also the definition that mainstream financial institutions such as the Bank for International Settlements and the International Monetary Fund have largely relied on. The second category is defined mainly by the TEN Group[4]. They define systemic risk as: financial events in the financial system that will lead to the decline of confidence and increase of uncertainty in the whole financial market. This definition is mainly from the perspective of social confidence caused by the collapse of the financial system. Panic behavior caused by the lack of confidence will eventually lead to the liquidity crisis in the originally safe financial system and then lead to the de facto financial crisis.

\subsubsection{Definition of Internet Finance}

Manuchehr Shahrokhi believes that Internet finance is a new financial model with obvious technological advantages, a large amount of information, and a broad information space [5]. Xie Ping and Zou Chuanwei were the first to put forward the concept of Internet finance in China [6]. Xie Ping found that electronic payment, transaction, and settlement were the conventional ways of Internet finance. In the process of specific information processing, it is necessary to rely on the support of information tools such as information association, index, and dissemination and the assistance of cloud computing technology and information sharing technology. With the strong support of the trinity, it is necessary to ensure that the development of Internet finance can obtain cheap and rich information reserves. In the link of resource allocation, Internet finance is not subject to the interference of other external factors. Therefore, Internet finance is fundamentally different from traditional finance in terms of financing mode, which is regarded as a brand-new financial mode. Wu 
Xiaoqiu proposed that Internet finance is a combination of the Internet and financial industry. A new financial industry developed by relying on cloud computing technology and big data and other network technologies with the help of the Internet platform [7].

\subsubsection{Research on the impact of Internet finance on commercial bank risks}

At present, there are two views in academic circles. The first view holds that Internet finance supplements traditional financial services, and the two form a complementary development state. Internet finance has a negative correlation with the risks of commercial banks. Franklin, James, and Philip think the use of electronic communications and computing more widely than before. Electronic financial will bring a lot of positive influence to financial institutions industry, speed up the financial sector, disintermediation services, and promote the efficiency of management. It makes the financial resources to obtain more convenient, for the current credit resources to obtain a powerful complement and improvement of the emergence of the Internet financial institutions may even make fundamental changes in the way of service [8]. To a certain extent, it reduces the risk-taking status of commercial banks. Berger An points out that Internet finance accelerates the optimization and integration of internal resources of the traditional banking industry. Technological progress may help promote the merger of the banking industry, improve the overall lending capacity, service quality, and product diversification of commercial banks, and improve the overall operational efficiency of the financial industry [9]. Chinese scholar Liu Zhonglu proposed that the development of the Internet forced commercial banks to speed up the innovation of the air duct system and rapidly improve their production and operation capacity, thus realizing the good effect of restraining the risk of bank bankruptcy [10]. Song Shouwen proposed the present stage of China's commercial Banks risk control system cannot meet the requirements of quantitative method and the process management, so still want to rely on past experience, under the big Internet financial situation, based on cloud computing technology combined with a large data of dual technology, promote the ascension of bank risk control system, makes every effort to the quantitative model of high accuracy, high predictability, to assist Banks in reducing bad credit and the main characteristics of the potential risk of bankruptcy [11].

The second view holds that because Internet finance squeezes the market and customers of traditional commercial banks, it will lead to more radical business models of commercial banks and increase the risks they take. Chinese scholar Man Yuanyuan pointed out that the interest rate must be analyzed and discussed in combination with the overall background of corresponding marketization [12]. In the study, the development of Internet finance will greatly affect commercial banks' income and related profits. Therefore, banks should carry out various internal rectifications and adjustments to improve the corresponding income. However, this structure cannot disperse the large stateowned banks whose net interest margin income is the main income. On the contrary, it will lead to the emergence of many risks, and at the same time, it will increase the credit risk of joint-stock banks, but it also has a positive role in dispersing the risk of commercial banks. Yu Weifeng conducted a professional study on the relevant characteristics of more than 60 domestic banks. In the research process, the relevant models of dynamic and panel are mainly adopted for demonstration, and the key point is to discuss how Internet finance will affect the profitability of banks. In the discussion process, the analysis believes that the risk of commercial banks will continue to increase with the continuous development of Internet finance [13]. At the same time, there is an obvious threshold effect between Internet finance and bank risks. That is, when the scale of banks continues to expand, Internet finance and bank risks show an obvious gradual process from no influence to the significant increase of bank risks and then to no influence at last. The development of Internet finance is positively correlated with the risks of commercial banks. Claessens, Kose, Terronesargued in their research that, compared with traditional finance, Internet finance only transforms the service mode and service concept of finance [14]. The low-cost advantage brought by technological innovation can expand the scale of deposits and loans of banks, and the network banking model can rapidly expand with the low-cost advantage and seize a larger market share. Arnold and Ewijkmade, a supplement on this basis, arguing that such economies of scale would also cause the accumulation effect of market risks, and regulatory control of risks should be strengthened for the banking model driven by information and communication technology [15]. Roger believes that it changes the business model of commercial banks and increases the risk-taking of banks, which will bring adverse effects on the stability of the financial system [16].

In terms of the definition of bank systemic risk, although the two mainstream views have different emphases, they are actually defined from the generation mechanism of systemic risk, which actually refers to the risk event caused by the overall liquidity depletion of the banking system and the normal operation difficulty caused by the decline of asset quality. There is no consensus on the definition of Internet finance, but most scholars believe that Internet finance is an emerging financial model, which is different from the traditional financial model. The main feature is the combination of financial activities and Internet technology to carry out 
financial activities. In the narrow sense, Internet finance is the behavior of non-traditional financial institutions to get involved in financial activities and carry out financial business through Internet technology. The Internet finance in this paper mainly refers to the Internet financial activities of third-party payment and $\mathrm{P} 2 \mathrm{P}$ network loans. In the research on the impact of Internet finance and commercial bank risks, most scholars believe that Internet finance positively correlates with the risks of commercial banks. That is, Internet finance will aggravate the risks of commercial banks. However, since the global Internet financial system has just been formed, no obvious risk spillover effect has been formed, leading to the majority of qualitative research. There is still room for development in the aspect of empirical analysis. To sum up, this paper will improve the quantitative research on the systemic risk of Internet finance and commercial banks based on extensive research on existing literature. Combining theoretical analysis with empirical analysis, this paper explores the systematic influence mechanism of Internet finance on commercial banks through quantitative research. It provides some suggestions for improving the supervision of Internet finance and risk control of commercial banks in terms of policies.

\subsection{Research Framework}

This paper mainly studies the impact of Internet finance on the systemic risk of the banking industry. At the same time, it analyzes the systemic risk of commercial banks under the background of Internet finance by data analysis. It discusses the relationship between the two from both qualitative and quantitative aspects. The specific content can be divided into six parts, arranged as follows: The first chapter is the introduction, including the research background, research significance, and literature review, as well as the research framework. The second chapter is the theoretical mechanism study and research hypothesis. The third chapter is the model construction and variable setting, mainly introduces the research samples and relevant data sources, variable setting and analysis, and the construction of regression model. The fourth chapter is the empirical research and results analysis. The fifth chapter is the conclusion and suggestion.

\section{THEORETICAL ANALYSIS OF THE IMPACT OF INTERNET FINANCE ON SYSTEMIC RISK OF CHINA'S LISTED BANKS}

\subsection{The Changing Habits of the User Community}

The year 2013 is the first year of Internet finance in China. China's traditional commercial banks have begun to be impacted by the new financing mode of Internet finance. With the progress of Internet technology and the improvement of modern communication equipment, a large number of Chinese people participate in Internet activities through mobile phones, and China has started to adopt the mobile Internet mode. As a result, the expanded group of Internet users has laid a foundation for the development of Internet finance, and people have a more diverse choice of payment methods.

Due to the frequent use of mobile phones, a large number of people choose to make mobile payments through mobile phones, and their consumption habits and lifestyle have been significantly changed. Due to the great demand for daily communication, users' stickiness to Internet payment is significantly enhanced compared with that before the popularization of mobile Internet. It can be seen from Figure 1 that the scale of third-party payment in China is in an expanding trend. From the perspective of the development history of China's thirdparty mobile payment market, it can be roughly divided into three stages according to the main growth points in different periods. The first stage is the online scenariodriven stage from 2013 to 2017 . The explosion of ecommerce, Internet finance, and money transfer has continuously promoted the rapid growth of mobile payment. The second stage is the offline scenario-driven stage from 2017 to 2019. In 2017, the scale of offline scrolling payment began to grow in an all-around way. The growth rate of offline scenario-based payment is much higher than that of online scenario-based payment, leading mobile payment to experience the transformation from the online scenario-driven stage to the offline scenario-driven stage. The third stage is the industrial payment driving stage starting from 2019. Online and offline payments driven by $\mathrm{C}$-terminal have entered a stable growth period due to the peak of $\mathrm{C}$ terminal traffic. With the rapid rise of the industrial Internet, industrial payment is gradually becoming a new growth point of China's mobile payment. 


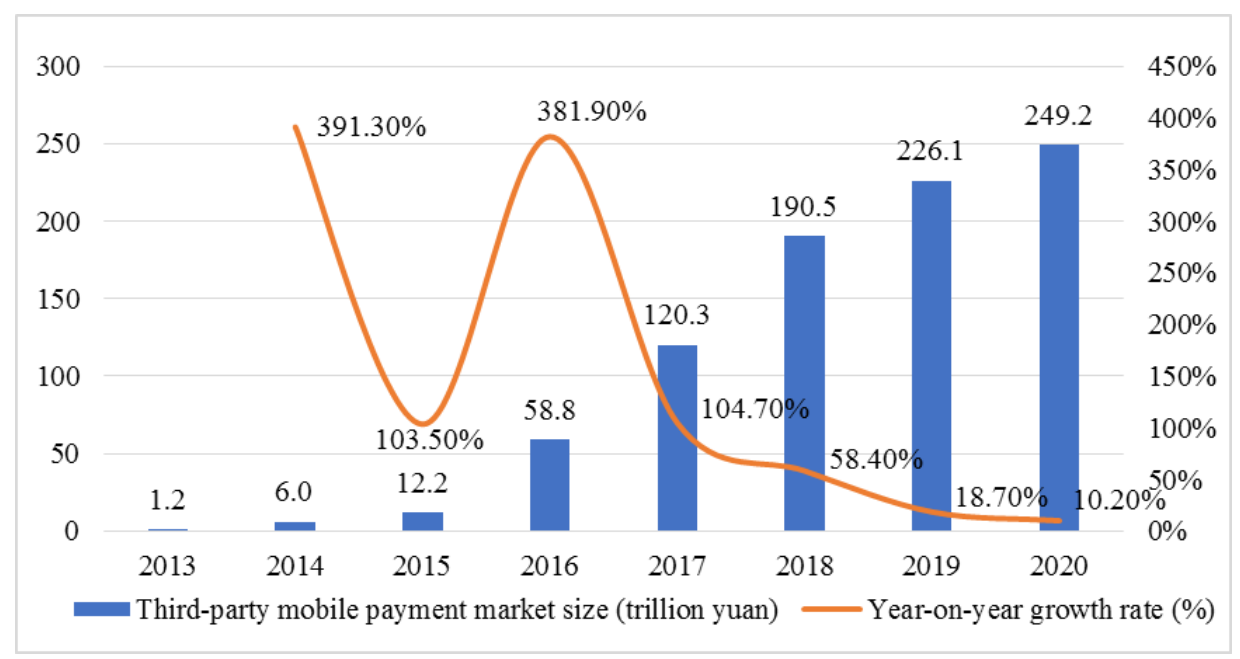

Figure 1. Scale of third-party mobile payment transactions in China from 2013 to 2020

Paid by figure 2 shows China's Internet users scale present a rising trend year by year, the user scale increased from 2013 in 260 million to 2017 in 530 million, the number of mobile payment users also showed increasing year growth and increased more than the growth of the Internet pay user scale, user scale increased from 2013 in 130 million to 2020 in 630 million. All these data show that users' payment habits have changed and that the Internet has a deeper impact on people's lives. Therefore, the traditional commercial banking business caused a certain impact. Internet financial in a simple and convenient operation, low-cost advantage, and attract more and more users a better user experience, especially by the mainstream financial markets limit of micro, small and medium enterprises loan, etc., expanding the scale of the Internet financial markets, broke the monopoly of the commercial Banks in the financial industry, the risk of the traditional banking.

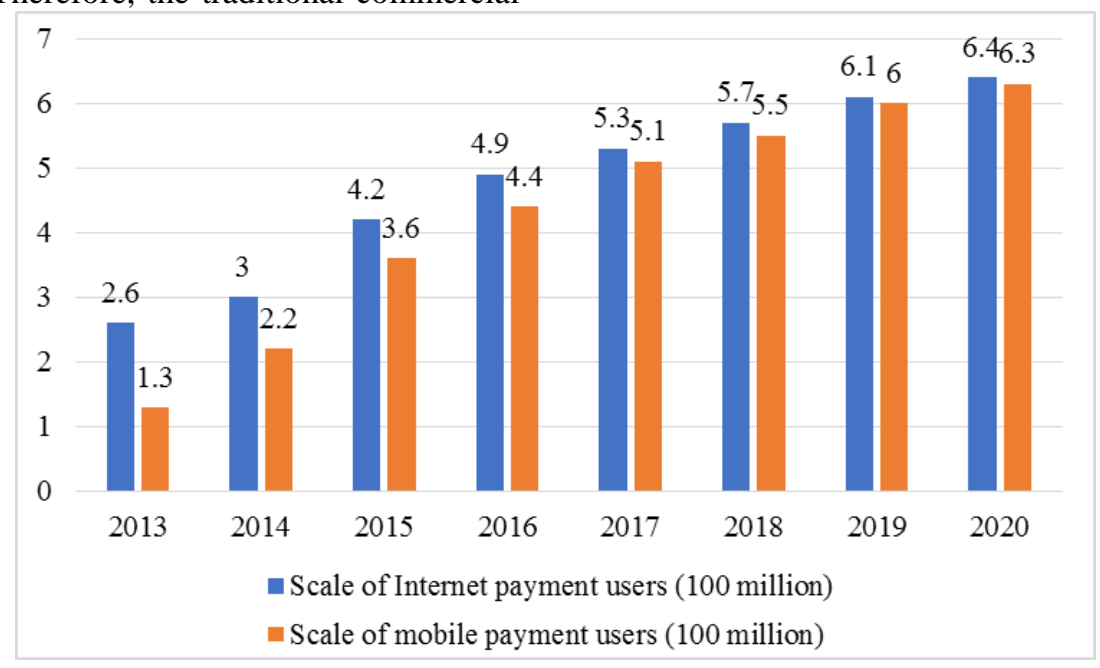

Figure 2. China's Internet and mobile payment users in 2013-2020

\subsection{Impact on Debt Business}

According to Zeng Jianguang's research based on the Long Tail Theory, Internet finance can attract the remaining $80 \%$ of investors and funds with relatively low transaction costs by virtue of advanced Internet technology advantages [17]. Online financial products of Internet finance have many advantages such as variety, high income, and convenient operation, which can meet people's increasingly diversified individual needs and attract more customers to buy Internet financial products, greatly reducing the customer group of banks. In addition, due to the time difference of thirdparty payment, when buyers and sellers use third-party payment platforms to conduct commodity transactions, a large number of funds will be retained on the platform to form precipitation funds, resulting in the loss of demand deposits of commercial banks. Typical products include Yu'ebao and Paypal. In 2013, China introduced a "pay for institutional clients cover management method", while the third-party payment institutions are required to have to be cover all capture puts in the related bank account, that money is finally back into the commercial Banks. Still, at the moment, the deposit has 
shifted by a personal checking account deposits or agreement for the company, the commercial Banks' liabilities structure has changed, to some extent, increased the liquidity of commercial bank liabilities costs and promoted liabilities is reduced, easy to induce a run on the risk and systemic risk.

\subsection{Impact on Asset Business}

Bank of China's asset business mainly refers to loan services. The credit activity that lends money according to certain interest rates and time limits includes working capital loan, fixed capital loan, and individual consumption loan. Due to the wide range of customer groups, Internet finance can squeeze out the loan services of commercial banks through lower cost and larger scale loan services. Taking P2P lending as an example, the biggest difference between P2P lending and traditional lending is that it directly faces customers. Traditional lending must go through the bank intermediary, while P2P lending directly provides customers with docking services. Relative to it, financing is more convenient and quicker. Traditional bank lending is low-cost access to capital, to a certain amount of interest paid out again, to seek the middle spreads, Banks need to resort the qualifications of a detailed review, see whether accord with standard of loans, in addition, to verify the qualifications of the guarantor, it will lead to the audit process is very long, but the interest will be higher. The emergence of P2P greatly simplifies the lending process and reduces the economic cost of borrowers. Internet financial management and insurance are becoming more and more popular among the public, which greatly facilitates people's life. However, it also inevitably occupies the market resources of many commercial banks, leading to the decline of their internal performance. In addition, services such as Huabei provided by Alipay and IOUs provided by JD are essentially credit card services, which are unnecessary for daily consumption and commercial banks' credit card services. Therefore, the asset services of banks are also impacted to a certain extent. Internet financial produced by the "catfish effect", will force the commercial Banks to ensure the growth of credit business in commercial bank itself more diverse business, such as low-interest business debt may reduce loan underwriting standards, into business has risk, high-interest rates, or the bank may risk degree is higher than before the product development, etc. These will undoubtedly increase the possibility of the occurrence of systemic risk of commercial banks.

\subsection{Impact on Settlement, Agency, and Custody Business}

Due to the rapid development of third-party payment, the payment and settlement business of the traditional banking industry has been greatly impacted. As payand-escrow third-party payment to obtain licenses, the development and innovation of business model, thirdparty payment application scenario has been covered, zhang remittance, ticketing, receiving financial expenses, insurance, and other large life scenes, greatly facilitate the life of people, resulting in a decrease of commercial bank charges and commissions, the impact on banking industry overall level of profitability. As Alipay tenpay wealth business model innovation, such as more fund and insurance company cooperation with Internet companies, users can already in the APP on buying insurance, funds to buy and so on, the impact on the agency business for Banks, as the Internet financial $2 \mathrm{~b}$ business gradually expanded, enterprise's credibility with the increase of development, further reducing the dependence on bank agency business. With the strengthening of cooperation between fund companies and Internet companies, money funds and public offering funds have found sales channels on many Internet APPs, such as Alipay and JD Finance. These third-party payments and other electronic payment platforms can better meet users' needs, which has a negative impact on the intermediary business of traditional commercial banks. The sale of various online insurance and financial products and the improvement of the stickiness of online payment by users have taken away some of the intermediary businesses of traditional commercial banks. It results in a significant reduction in commercial banks' fees and commission income, a decline in the income level of commercial banks, and risk of profitability of commercial banks.

\subsection{The Risks of Internet Finance Itself Have Spill-over Effects}

As Internet finance provides financial services to users with the support of big data and other Internet technologies, information technology itself inevitably has technical loopholes, such as immature technology development and network system failure, which will bring technical risks. Due to the lack of relevant laws and regulations and industry autonomous associations to regulate the development of Internet finance, its internal control mechanism may not be perfect. In addition, the backward business level and quality of employees in the Internet financial platform will lead to operational mistakes in work, which may bring operational risks. At the same time, the construction of laws and regulations on Internet finance is still in the early stage of development, which cannot keep up with the pace of development of Internet finance. As a result, some businesses may lack supervision and encourage criminals to carry out business with the help of legal loopholes, resulting in legal risks. Credit risk is one of the major problems of the Internet financial with the long tail to attract the masses of micro, small and medium enterprises, and individuals while expanding 
the user base. Still, some of these customers may not conform to the traditional borrowing qualifications, at the same time, the Internet has certain information noise, only by the data of online estimate is very difficult to guarantee the authenticity of the information, could lead to credit risk. Although there are certain differences between Internet finance and traditional finance, Internet enterprises still rely on commercial banks to carry out financial activities fundamentally. There is a certain spillover of financial risks of Internet enterprises, which has a synergistic effect on the risks of commercial banks themselves on the whole. If the above risks infect commercial banks, it will sow hidden dangers for the overall systemic risk of commercial banks.

Therefore, based on the above analysis and literature reading, the following hypotheses are proposed:

Hypothesis H1: Internet finance is positively correlated with the systemic risk of commercial banks. That is, Internet finance aggravates the systemic risk of commercial banks.

Hypothesis H2: With the development of Internet finance, the ratio of deposits to loans of commercial banks may rise, and the degree of systemic risk to commercial banks will be greater.

\section{MODEL CONSTRUCTION}

\subsection{Samples and Data Sources}

As of April 30, 2021, there are 54 listed banks in China, including $15 \mathrm{~A}+\mathrm{H}$ shares, $23 \mathrm{~A}$ shares, and $16 \mathrm{H}$ shares listed banks, whose total assets and net profits account for $82 \%$ and $91 \%$ of all commercial banks in China, respectively [18]. Among them, there are 6 large commercial banks, 10 national joint-stock commercial banks, 28 urban commercial banks, and 10 rural commercial banks. Banks listed on $\mathrm{H}$ shares are excluded. Based on the background of the implementation of the new accounting standards in 2007 and the first year of Internet finance in 2013, this paper takes the data of 16 banks listed on the Shanghai and Shenzhen stock markets from the fourth quarter of 2010 to the fourth quarter of 2020 as the research sample. Including five big state-owned banks: Industrial and Commercial Bank of China, China Construction Bank, Agricultural Bank of China, Bank of Communications, Bank of China. There are eight national joint-stock banks: Commercial Bank, Ping An Bank, Huaxia Bank, China Minsheng Bank, China Everbright Bank, Industrial Bank, Pudong Development Bank, China Merchants Bank, China Citic Bank, and three city commercial banks, Bank of Nanjing, Bank of Ningbo and Bank of Beijing.
The selection of data indicators and modelling design in this part refers to Xu Hui's paper[19]. Data about banks in this paper are from the Wind database and CSMAR database. The data of Internet finance are mainly from the website of iResearch Consulting and the website of Analysis Think Tank, which are collected and sorted by myself manually. In the process of data processing, there are some missing data, for which the average interpolation method is used to calculate. The research tool used in this paper is STATA16.0 statistical software.

\subsection{Variable Setting and Analysis}

\subsubsection{Explained Variable}

In this paper, the systemic risk of commercial banks is measured by the Bank Systemic Risk Index, which adopts the beta value of the industry.

\subsubsection{Explanatory Variables}

The explanatory variable in this paper is Internet finance. Reference is made to Xu Hui's construction of Internet finance indicators and $\mathrm{Wu}$ Chengsong's definition of Internet finance and the division of its development stages $[19,20]$. The growth rate of the transaction volume of third-party Internet payment and $\mathrm{P} 2 \mathrm{P}$ online loans is taken as the expression of Internet finance. In addition, WIF is introduced to set the value of Internet finance as 0 in 2013 and 1 in 2013.

\subsubsection{Control Variable}

There are 7 control variables in this paper. The first control variable is the economic growth rate, which EGR represents, which is the growth rate of the GDP. EGR reflects the level and state of national economic development. The macroeconomic cycle has a strong impact on the stability of the financial system, so GDP is considered. The second control variable is the ratio of non-performing assets. At present, the main risk of China's commercial banks is still credit risk, among which the ratio of non-performing assets is an important indicator to judge the extent to which banks are affected by credit risks and is represented by NPA. The third control variable is the scale of bank assets. In this paper, the current scale of bank assets is represented by LNAS through logarithmic smoothing processing. The fourth control variable is the capital adequacy ratio, an important indicator of risk management of commercial banks. The higher the capital adequacy ratio is, the stronger the resistance to credit risk and market risk is, indicating the lower possibility of systemic risk of the bank, which is represented by CAR. The fifth control variable is the return on equity, which reflects the profitability of a bank. The higher the value, the stronger the bank's profitability and the stronger its 
resistance to bank risks. ROE represents this value. The sixth control variable is the deposit/loan ratio. The higher the deposit/loan ratio is, the more favorable the bank's earnings will be, represented by LDR. The seventh control variable is the cost-income ratio, which reflects the operating expenses and the most important index of the relationship between expenses and inputoutput, and is expressed by CIR.

Table 1. Variable definition table

\begin{tabular}{|c|c|c|c|}
\hline & Variable name & Variable definitions & Variable symbol \\
\hline Explained variable & The systemic risk of banks & The $\beta$ of the commercial bank industry. & Risk \\
\hline \multirow{2}{*}{$\begin{array}{l}\text { Explanatory } \\
\text { variables }\end{array}$} & Internet Finance & $\begin{array}{l}\text { The growth rate of the transaction volume of } \\
\text { third-party Internet payment }\end{array}$ & INF \\
\hline & $\begin{array}{l}\text { Degree of development of } \\
\text { Internet finance }\end{array}$ & $\begin{array}{l}\text { Before } 2013 \text { the variable is } 0 \text {, After 2013, the } \\
\text { variable is } 1\end{array}$ & Wif \\
\hline \multirow{7}{*}{ Control variables } & economic growth rate & The GDP growth rate & Egr \\
\hline & Non-performing assets ratio & $\begin{array}{l}\text { The ratio of the bank's total non-performing } \\
\text { loans to the bank's total loan balance at the end } \\
\text { of the year }\end{array}$ & Npa \\
\hline & The size of the bank's assets & $\begin{array}{l}\text { The current asset scale of the bank adopts } \\
\text { logarithmic smoothing }\end{array}$ & LnAS \\
\hline & capital adequacy ratio & $\begin{array}{l}\text { The ratio of a bank's total capital to its total } \\
\text { risk-weighted assets }\end{array}$ & Car \\
\hline & return on equity & $\begin{array}{l}\text { A bank's return on equity in the current period } \\
\text { reflects the return on owners' equity }\end{array}$ & Roe \\
\hline & Deposit to loan ratio & $\begin{array}{l}\text { The ratio of the loan balance to deposit } \\
\text { balance }\end{array}$ & LDR \\
\hline & Cost-Income Ratio & $\begin{array}{l}\text { Reflect operating expenses and expenses and } \\
\text { input-output relationship }\end{array}$ & Cir \\
\hline
\end{tabular}

\subsection{Model Construction}

The modelling design in this part refers to Xu Hui's paper [19]. According to the above analysis and model assumes that the following model was constructed to carry on the empirical test, the regression model (1) studied the influence of the Internet financial systemic risk in the commercial bank, the regression model (2) studied the degree of financial development of the Internet influence on systemic risk of the commercial bank, in addition, due to show the degree of influence on the systemic risks of commercial Banks, at the same time, considering the bad assets ratio, net assets yield, capital adequacy, LDR, bank assets, cost-income ratio, and macro indicators growth rate will affect bank systemic risk, therefore, They were all incorporated into the regression model as control variables.

$$
\begin{aligned}
\operatorname{Risk}_{i j}=\beta_{0}+ & \beta_{1} I N F_{i j}+\beta_{2} N p a_{i j}+\beta_{3} \operatorname{Roe}_{i j} \\
& +\beta_{4} \operatorname{Car}_{i j}+\beta_{5} \operatorname{Cir}_{i j}+\beta_{6} L D R_{i j} \\
& +\beta_{7} \operatorname{Egr}_{i j}+\beta_{8} L n A S_{i j}+\xi_{i j}
\end{aligned}
$$

$\beta$ represents the regression parameters of each variable index, and subscript Ij represents the index of the bank in the JTH year and represents the regression residual. $\xi_{i j}$ Other variables are defined in Table 1 .

$$
\begin{aligned}
\text { Risk }_{i j}=\beta_{0}+ & \beta_{1} W_{i f}+\beta_{2} N p a_{i j}+\beta_{3} \operatorname{Roe}_{i j} \\
& +\beta_{4} \operatorname{Car}_{i j}+\beta_{5} \operatorname{Cir}_{i j}+\beta_{6} L D R_{i j} \\
& +\beta_{7} E g r_{i j}+\beta_{8} L n A S_{i j}+\xi_{i j}
\end{aligned}
$$

Among them, Risk represents the systemic Risk of commercial banks, WIF represents the development degree of Internet finance, $\beta$ represents the regression parameters of each variable index, and subscript $\mathrm{Ij}$ represents the index of the bank in the JTH year and represents the regression residual. $\xi_{i j}$ Other variables are defined in Table 1.

\section{EMPIRICAL RESEARCH AND RESULT ANALYSIS}

\subsection{Descriptive Statistical Analysis}

Among them, Risk represents the systemic Risk of commercial banks, INF represents the Internet finance,

Table 2. Descriptive Statistics

\begin{tabular}{llllll}
\hline & $\mathrm{N}$ & mean & $\mathrm{sd}$ & $\min$ & $\max$ \\
\hline inf & 704 & 15.42 & 13.19 & -10.54 & 69.66 \\
egr & 704 & 7.166 & 2.639 & -6.800 & 12.20 \\
npa & 704 & 1.193 & 0.444 & 0.34 & 2.400 \\
lnas & 704 & $7.288 \mathrm{e}+12$ & $7.517 \mathrm{e}+12$ & $1.74 \mathrm{e}+11$ & $3.347 \mathrm{e}+13$ \\
car & 704 & 12.02 & 3.319 & 8.31 & 17.52 \\
roe & 704 & 4.080 & 1.314 & -0.569 & 7.413 \\
ldr & 704 & 73.19 & 16.29 & 42.68 & 116.0
\end{tabular}




\begin{tabular}{llllll} 
cir & 704 & 28.08 & 5.530 & 15.1432 & 46.96 \\
wif & 704 & 0.727 & 0.446 & 0 & 1 \\
risk & 704 & 0.863 & 0.375 & -0.101 & 2.724 \\
\hline
\end{tabular}

Table 2 presents the descriptive statistical results of relevant research variables. As can be seen from the data in the table, the mean value, minimum value, maximum value, and standard deviation of the explained variable Risk of commercial banks is 0.863 , $0.101,2.724$, and 0.375 , indicating that the development of China's banks is not stable in the past decade. The overall Risk gap fluctuates to a certain extent. Relevant departments should pay attention to the development of the banking financial environment. The mean value, standard deviation, minimum value, and maximum value of INF of the explanatory variable Internet finance are $15.42,13.19,-10.54$, and 69.66 , indicating that the development speed of China's Internet finance has been relatively obvious in the past decade and its growing power is relatively large. The mean value, standard deviation, minimum value, and maximum value of EGR of economic growth rate are 7.166, 2.639, -6.8, and 12.2, indicating that China's economic growth is in good condition and the overall economic environment is healthy. Although COVID-19 causes the negative growth rate, the overall trend is stable and positive. The non-performing assets ratio of the average index of npa is 1.193 , the standard deviation is 0.444 , the minimum value is 0.34 , the maximum value of 2.4 , shows that the whole of China commercial bank asset quality is relatively stable, but there is still some difference of asset quality, considering the different audience bank customers, maybe due to differences in geographical and customer. The mean value of bank asset size index LNAS is $7.288 \mathrm{e}+12$, the standard deviation is $7.517 \mathrm{e}+12$, and the minimum value is $1.74 \mathrm{e}+11$. The maximum value is $3.347 \mathrm{e}+13$, indicating that there is a certain gap between the assets of various banks in China. The different total asset sizes of banks lead to the different risk tolerance of individual banks.

The mean value, standard deviation, minimum value, and maximum value of CAR of capital adequacy ratio are $12.02,3.319,8.31$, and 17.52. The capital adequacy ratio is an important risk measurement index of China's commercial banks, and the level of risk shock resistance of China's commercial banks is obviously greatly different. The mean value, standard deviation, minimum value, and maximum value of ROE are 4.080, 1.314, 0.569 , and 7.413 , indicating that there are certain differences in the profitability level of commercial banks in China, which is related to the asset status of banks and the quality of their human resources. The average value of the LDR of banks is 73.19, the standard deviation is 16.29 , the minimum value is 42.68 , and the maximum value is 116.0 , indicating a large gap between deposits and loans different banks in China. Some banks have high operating costs and low-risk tolerance. The cost-income ratio index CIR, with a mean value of 28.08, a standard deviation of 5.530 and a minimum value of 15.1432 , and a maximum value of 46.96, indicates that there are great differences in operating efficiency of different banks, which is related to the rational allocation of resources and risk tolerance of different banks.

\subsection{Correlation Analysis}

The correlation analysis of the main variables studied in this paper is shown in Table 3. It can be seen from the results that the coefficient value of each variable does not have a higher value, which excludes the multicollinearity problem of the variable, indicating that the selection of variables in the study is effective. From the numerical point of view, the development of Internet finance has a high correlation with economic growth, which proves that the development of Internet finance plays a promoting role in economic growth. At the same time, Internet finance can restrain banks' loanto-deposit ratio to a certain extent, proving that Internet finance can affect the risks of commercial banks by inhibiting the loan-to-deposit ratio. It can also be seen that the non-performing assets ratio has a significant negative correlation with the systemic risk coefficient beta of banks, which proves that the asset quality of commercial banks has a significant impact on their systemic risk coefficient. The economic growth rate is positively correlated with the coefficient $\beta$ of systemic risk of banks. It is speculated that Internet finance has a great impact on economic growth and the influence of Internet finance spillovers, which increases the systemic risk of banks.

Table 3. Correlation analysis

\begin{tabular}{|c|c|c|c|c|c|c|c|c|c|c|}
\hline Variables & risk & inf & wif & egr & npa & lnas & car & roe & $\mathrm{idr}$ & cir \\
\hline risk & 1.000 & & & & & & & & & \\
\hline $\inf$ & 0.000 & 1.000 & & & & & & & & \\
\hline wif & -0.054 & -0.085 & 1.000 & & & & & & & \\
\hline egr & $0.152^{*}$ & $0.327 *$ & $-0.515^{*}$ & 1.000 & & & & & & \\
\hline npa & $-0.413^{*}$ & -0.090 & $0.545 *$ & $-0.383^{*}$ & 1.000 & & & & & \\
\hline lnas & $-0.467 *$ & $-0.097 *$ & $0.234 *$ & $-0.216^{*}$ & $0.419 *$ & 1.000 & & & & \\
\hline car & $-0.234^{*}$ & $-0.111 *$ & $0.215^{*}$ & $-0.301 *$ & $0.382 *$ & $0.457 *$ & 1.000 & & & \\
\hline roe & $0.246^{*}$ & 0.093 & $-0.490 *$ & $0.420^{*}$ & $-0.549 *$ & $-0.182 *$ & $-0.291 *$ & 1.000 & & \\
\hline
\end{tabular}




\begin{tabular}{|c|c|c|c|c|c|c|c|c|c|c|}
\hline $\begin{array}{l}\text { ldr } \\
\text { cir }\end{array}$ & $\begin{array}{l}-0.130^{*} \\
0.305^{*}\end{array}$ & $\begin{array}{l}-0.145^{*} \\
0.141^{*}\end{array}$ & $\begin{array}{l}0.314 * \\
-0.367 *\end{array}$ & $\begin{array}{l}-0.302 * \\
0.328 *\end{array}$ & $\begin{array}{l}0.527 * \\
-0.265 *\end{array}$ & $\begin{array}{l}0.102 * \\
-0.317 *\end{array}$ & $\begin{array}{l}0.356^{*} \\
-0.053\end{array}$ & $\begin{array}{l}-0.360 * \\
0.190 *\end{array}$ & $\begin{array}{l}1.000 \\
-0.070\end{array}$ & 1.000 \\
\hline & & & & & & & & & $-0.0 / 0$ & 1.000 \\
\hline
\end{tabular}

\subsection{Regression Analysis}

Table 4. Model regression results

\begin{tabular}{|c|c|c|}
\hline & Model 1 & Model 2 \\
\hline inf & $\begin{array}{l}-0.002 * \\
(-1.65)\end{array}$ & \\
\hline wif & & $\begin{array}{l}0.300 * * * \\
(8.74)\end{array}$ \\
\hline npa & $\begin{array}{l}-0.213 * * * \\
(-5.45)\end{array}$ & $\begin{array}{l}-0.315^{* * *} \\
(-8.13)\end{array}$ \\
\hline roe & $\begin{array}{l}0.019 \\
(1.64)\end{array}$ & $\begin{array}{l}0.038 * * * \\
(3.44)\end{array}$ \\
\hline car & $\begin{array}{l}-0.000 \\
(-0.08)\end{array}$ & $\begin{array}{l}0.001 \\
(0.30)\end{array}$ \\
\hline cir & $\begin{array}{l}0.010 * * * \\
(4.33)\end{array}$ & $\begin{array}{l}0.014 * * * \\
(6.11)\end{array}$ \\
\hline ldr & $\begin{array}{l}0.001 \\
(1.14)\end{array}$ & $\begin{array}{l}0.001 \\
(1.36)\end{array}$ \\
\hline egr & $\begin{array}{l}-0.009 \\
(-1.56)\end{array}$ & $\begin{array}{l}0.003 \\
(0.54)\end{array}$ \\
\hline lnas & $\begin{array}{l}-0.000 * * * \\
(-8.02)\end{array}$ & $\begin{array}{l}-0.000^{* * * *} \\
(-8.09)\end{array}$ \\
\hline Constant & $\begin{array}{l}0.880 * * * \\
(7.58)\end{array}$ & $\begin{array}{l}0.454 * * * \\
(3.79)\end{array}$ \\
\hline $\begin{array}{l}\text { Observations } \\
\text { R-squared } \\
\text { F }\end{array}$ & $\begin{array}{l}704 \\
0.303 \\
37.82 \\
\end{array}$ & $\begin{array}{l}704 \\
0.370 \\
50.99 \\
\end{array}$ \\
\hline
\end{tabular}

As shown in Table 4, model 1 studies the systematic risk coefficient beta of commercial banks and the analysis of Internet finance and the fundamentals of commercial banks. Model 2 studies the beta of the systemic risk coefficient of commercial banks, the development degree of Internet finance, and the analysis and research of the fundamentals of commercial banks. It can be observed from Model 1 that the correlation coefficient of the non-performing assets ratio is -0.213 , which has a significant negative impact on the systemic risk coefficient of commercial banks in Model 1 and Model 2. In Model 2, it can be clearly found that the coefficient of Internet development degree is 0.3 , which promotes the systemic risk of commercial banks, which is consistent with Hypothesis 2.

\section{CONCLUSION}

The risk of commercial banks is affected by many aspects, among which the development degree of Internet finance has an obvious promoting effect on the systemic risk of commercial banks. Its correlation coefficient is 0.3 , and it has passed the test at the confidence level of $1 \%$. It shows that with the growth of mobile Internet users in China and the gradual increase of users' stickiness to Internet finance, traditional commercial banks lose customer groups, which aggravates the emergence of systemic risks in commercial banks. The emergence of new financial financing models will have a certain impact on the business of traditional banks. Internet finance will have a certain impact on commercial banks' liabilities, assets, agency, and custody business. By diverting the mainstream business of commercial banks, it will impact the profit of commercial banks. Make the commercial bank liquidity risk, credit risk, and so on.

Based on the above research results and in the current context, the following suggestions are put forward for commercial banks and Internet finance. The first is to change the business philosophy and win more customers with the help of the development of digital RMB. Secondly, we should actively cooperate with Internet financial enterprises. Thirdly, Internet financial 
enterprises should launch detailed business capability division documents and supervision plans. Due to the low threshold of Internet finance business, many customers with low-risk tolerance and debt repayment ability directly participate in financial activities through Internet finance. There have been Alipay Huabei, Jingdong IOU overdue, and the need for multiple instalments. Although Internet finance promotes residents' willingness to consume, it also expands the overall debt level of society. If there is an economic downturn, the debt risk of Internet finance may lead to regional crises. Therefore, the relevant industries of Internet finance should be supervised, and autonomous industry organizations and regulatory organizations should be established to prevent large-scale financial risks.

\section{REFERENCES}

[1] Zhao Xianghua.(2019). Influence of Internet Finance on Residents' Financial Investment Activities.China Economic and Trade Review (11),96-97.

[2] Stiglitz, J. Distribution of income and wealth among individuals[M]. Econometrica Vol.37, No.3, 1969 .

[3] Kaufrman, George G.Comment on systemic risk (J).Research in Financial sercices: Banking, Financial Markets and Systemic Risk,1995.

[4] Group of Ten. Report on consolidation in the financial sector(M). publisher notidentified,2001.

[5] Mehran J, Shahrokhi M. An application of four foreign currency forecasting models to the U.S. dollar and Mexican peso[J]. Global Finance Journal, 2008, 8 (2) : 211-220.

[6] Xie Ping, Zou Chuanwei, Liu Haier.The basic theory of Internet finance [J]. Financial Research, 2012(8): 1-12.

[7] $\mathrm{Wu}$ Xiaoqiu.Internet finance: the logic of growth [J]. Finance and Trade Economics, 2015, 36(2): 515.

[8] Franklin A., James M., and Philip S. E-Finance: An Introduction[J]. Journal of Financial Services Research,2002(25):5-27.
[9] Berger A N. The Economic Effects of Technological Progress: Journal of Financial Credit \& Banking, 2003,35 (2):141-176.

[10] Liu Zhonglu, Lin Zhangyue. Research on the Impact of Internet Finance on Commercial Banks' Profits [J]. Beijing Social Sciences,2016(9): 61-72.

[11] Song Shouwen, Dai Qian, Chai Ruoqi. Internet + bank: New reform of risk management of traditional commercial banks in China $[\mathrm{J}]$. Science of Finance and Economics, 2015(7): 10-18.

[12] Man Yuanyuan. The impact of income diversification and financial liberalization on the performance and risk of commercial banks $[\mathrm{J}]$. Macroeconomic Research, 2016(01): 20-25.

[13] $\mathrm{Yu}$ Weifeng, Zhou Dai. Internet finance, commercial bank scale and risk taking [J]. Journal of Yunnan University of Finance and Economics, 2018(1): 59-69.

[14] Claessens S, Kose M A, Terrones M E. How do Business and Financial Cycles Interact?[J].Journal of International Economics, 2012,87 (1):178-190.

[15] Arnold I J M, Ewijk S E V. Can Pure Play Internet Banking Survive the Credit Crisis?[J].Journal of Banking \& Finance, 2011,35 (4):783-793.

[16] Roger,N., Concordant E., Concordant E., Concordant E., Concordant E.

[17] ZENG Jianguang. Network security risk perception and asset pricing of Internet finance [J]. Economic Research Journal, 2015(7):131-145.

[18] Ernst \& Young, Review and Future Prospects of China's Listed Banks in 2020

[19] Xu Hui. Research on the Impact of Internet Finance on the Systemic Risk of Commercial Banks in China _ Xu Hui [J].Wu Chengsong, Zhou Wei, Zhang Peng.

[20] Wu Chengsong, Zhou Wei, Zhang Peng. Research on the influence of Internet finance on the innovation ability of banks: Empirical evidence from 62 cities [J].Journal of Guizhou University of Finance and Economics, 2016(3):54-65. 